This is an electronic reprint of the original article. This reprint may differ from the original in pagination and typographic detail.

Author(s): Granbom-Herranen, Liisa

Title: $\quad$ Nykypäivän sananlaskujen hullu

Year: $\quad 2016$

Version:

Please cite the original version:

Granbom-Herranen, L. (2016). Nykypäivän sananlaskujen hullu. Elore, 23(1).

http://www.elore.fi/arkisto/1_16/granbom-herranen.pdf

All material supplied via JYX is protected by copyright and other intellectual property rights, and duplication or sale of all or part of any of the repository collections is not permitted, except that material may be duplicated by you for your research use or educational purposes in electronic or print form. You must obtain permission for any other use. Electronic or print copies may not be offered, whether for sale or otherwise to anyone who is not an authorised user. 


\title{
NYKYPÄIVÄN SANANLASKUJEN HULLU
}

\author{
Liisa Granbom-Herranen
}

$\mathrm{K}^{\mathrm{a}}$ atsaukseni tavoitteena on selvittää hulluuden käsittelyä ilmiönä 2000-luvulla käytetyissä sananlaskuissa. Aineistona ovat mielipiteinä julkaistaviksi tarkoitettuihin tekstiviesteihin vuosina 2006-2010 sisältyneet sananlaskut. Kuvaan sananlaskujen ja viestien avulla näkemystä hullusta ja siitä, kuinka hullun käyttäytymistä niissä määritetään. Tarkasteltaessa hulluutta sananlaskujen yhteydessä tutkitaan sitä, millaisia piirteitä kytkeytyy käsitteeseen hullu sekä laajemmin sitä, millaisena ilmiönä hulluus sananlaskujen yhteydessä näyttäytyy.

Olen päätynyt tarkastelemaan sekä hulluutta että tyhmyyttä, sillä suomalaisten sananlaskuaineistojen perusteoksissa ${ }^{1}$ sananlaskuissa yhdistyvät usein hulluus ja tyhmyys. Kyse on siitä, kuinka nykyisin käytössä olevien sananlaskujen kautta määritellään hulluutta ja tyhmyyttä, jotka molemmat määrittävät käsitystä hulluudesta. Tässä sananlaskujen tarkastelun lähtökohtaoletuksena on ollut, että sananlasku elää jossakin kontekstissa ja sen tulkinta edellyttää kontekstitietoutta. Kontekstiinkaan kiinnittyessään sananlaskuja ei kuitenkaan voi tulkita tukeutumalla edes keskeisimpään käsitteeseen eli kiinnittämällä aineistossa huomiota vain tiettyyn sanaan. Saneet eli perusmuotoisina tai taivutettuina olevat sanat määrittävät käsitteitä hullu ja tyhmä, jotka puolestaan kuvaavat ilmiöitä. Käytetyt sananlaskut ovat osittain samoja kuin ne ovat olleet jo 1800-luvulla, mutta niiden voidaan olettaa saaneen uusia merkityksiä. Aineiston tarkastelun alkuvaiheessa syntyi mielikuva, että hulluus ja tyhmyys kuvataan keskenään samanlaisina ilmiöinä eikä kumpikaan niistä yhdisty sairauteen. Aivan näin ei kuitenkaan tekstiviestien sananlaskuissa osoittautunut olevan.

Katsauksen ensimmäisessä luvussa tarkastelen käsitteen sananlasku (engl. proverb) määrittelyä artefaktina tekstiviestien kontekstissa. Sitä seuraava luku taustoittaa ilmiönä hulluutta sekä sen määrittelyn ja yhteisön suhdetta aikana, joka on jättänyt jälkeensä tämän päivän mielisairaanhoitoa koskevaan lainsäädäntöön, käsityksiin hulluudesta ja suomalaisiin sananlaskuihin. Aineistoa ja menetelmää käsittelevässä luvussa kuvaan lyhyesti sitä julkaisuympäristöä, johon tekstiviestit on suunnattu, käytettyä sananlaskuaineistoa sekä sisällönanalyysin (engl. content analysis) toteutusta tässä tutkimuksessa. Johtopäätöksiä edeltävä ja viimeinen

1 Pääosa niin sanotuista traditionaalisista suomalaisista sananlaskutyypeistä sisältyy seuraaviin julkaisuihin, joita voi kutsua suomalaisten sananlaskuaineistojen perusteoksiksi: Kuusi 1990 (vanhimmat Turun paloon mennessä kootut), Nirvi \& Hakulinen 1953 (1930-luvulla kerätyt) ja Laukkanen \& Hakamies 1997 (1900-luvun puoleenväliin asti kerätyt). Artikkelissa käytän näistä teoksista lyhenteitä K 1990, N\&H 1953 ja L\&H 1997. 
Liisa Granbom-Herranen: Nykypäivän sananlaskujen hullu

[http://www.elore.fi/arkisto/1_16/granbom-herranen.pdf]

analyysiluku käsittelee sitä, millaisia asioita hulluudesta sekä siihen liittyvästä tyhmyydestä kerrotaan tekstiviestien sananlaskujen avulla.

\section{SANANLASKU ON ARTEFAKTI TEKSTIVIESTISSÄ}

Paremiologia² tuntee ja käyttää useita erilaisia sananlaskun määritelmiä (ks. Mieder 2004). Tämä on seurausta siitä, että käsitettä sananlasku ei toistaiseksi ole onnistuttu pyrkimyksistä huolimatta määrittelemään täydellisesti (Dundes1981, 44). Nykyisin käsitettä sananlasku käytetään paremiologiassa varsin yleisesti merkityksessä sananlasku ja sananlaskun kaltainen ilmaisu - tarkasteltaessa niin arjen emic- kuin paremiologian etic-kieltä. Käsitteen kattavuus on laajentunut emic-kielen suuntaan. (Ks. esim. Granbom-Herranen \& Lauhakangas 2015 sekä Proverbium.) Ilmaisun sananlaskuksi todentavia tai sen traditionaalisiin ja moderneihin sananlaskuihin jakavia yleispäteviä lauseen ominaisuuksia ei ole määriteltävissä. ${ }^{3}$

Kuten Lauri Honko $(1989,14)$ on todennut, aina ei ole välttämätöntä tai edes mahdollista pitää liian tiukasti kiinni tutkimuskäsitteistöstä, sillä uusille käytännöille tulee olla sijaa. Jokapäiväisessä käytössä yksittäinen sananlasku elää niin kauan kuin siihen viitataan ja viittaus tunnistuu. Tämä tarkoittaa, että tarkasteltaessa sananlaskuja nykyisissä käyttökonteksteissa on etsittävä sekä sananlaskuja että niiden osia sekä viittauksia niihin (Granbom-Herranen 2013, 2014 \& 2016). Tarkastelen suomalaista sananlaskua lyhyenä, väittämän sisältämänä kannanottona, joka on tai on ollut tuttu ja käytetty ajan ja paikan muodostamassa tilassa. Mikäli sananlasku ei täytä tuttuuden (engl. familiarity) vaatimusta, ei siitä voi tulla käytössä yleistä (engl. frequency) (Grzybek 1987, 73; Granbom-Herranen 2016).

Sananlasku on kulttuurinen artefakti eli taitoteos, joka yhdistää kreikankieliset käsitteet artes ja factos. Se on tuotos, jolla on kohtuullisen kiinteä olemus, mutta sen merkitys syntyy aina käytön yhteydessä. Se on samalla sekä lopputuote että pienen performanssin kaltainen prosessi; se on taitoa ja tekemistä päämääränään jotakin, jolla on käyttöarvoa. Kuten artefakti yleensä, sananlaskukin on keinotekoinen tuote, ei luonnosta löytyvä entiteetti. Artefaktien - ja myös sananlaskujen olemassaolon syy on inmisten päämäärissä ja niihin liittyvissä tarpeissa (Lee 1999, 2). Artefaktina sananlaskun käyttö edellyttää sekä tietoa sananlaskusta että taitoa sen käytöstä (ks. Niiniluoto 2000, 25-27). Yksilöllisenä kokemuksena ei sananlaskulla ole varsinaisesti merkitystä, sillä sananlasku elää ainoastaan yhteisöllisessä vuorovaikutuksessa (ks. Goodman 1985, 68, 79-80).

Suullinen perinne on löytänyt tiensä arkikirjoittamiseen, ja nykyisin suurin osa kommunikaatiosta on kirjallisessa muodossa, kuten tässä yhteydessä aineiston muodostavissa mielipidekirjoituksina käytetyissä tekstiviesteissä. Muodoltaan viestit ovat lähempänä puhekieltä kuin kirjallista tuotetta. Tekstiviestit ovat varsin matalan

2 Sananlaskujen tutkimus eli paremiologia hyödyntää usein sananlaskujen keruun, paremiografian, tuottamia aineistoja.

3 Käsite moderni sananlasku tai uusi sananlasku (engl. modern proverb) on ongelmallinen, sillä sen vastinparina käytetään yleensä käsitettä traditionaalinen tai perinteinen sananlasku (engl. traditional proverb) - aivan kuin nykyperinnettä ei olisi (ks. esim. Granbom-Herranen 2015 \& 2016; Granbom-Herranen ym. 2015). 2000-luvulla määrittely-yritykset ovat kohdistuneet lähinnä jonkin kieli- tai kulttuurialueen omiin tarpeisiin (Reznikov 2009, 4-5, 177-179). 
kynnyksen kommunikointikanavia. Katsauksessani sananlasku voi siis tarkoittaa myös viittausta sananlaskuun, kuten esimerkiksi sananlaskun alkuosan käyttöä. Tämäkin kertoo sananlaskun tuttuudesta, kuulijan (lukijan) oletetaan tunnistavan ilmaisu. Tässä sananlaskujen tulkinnan viitekehyksenä on sananlaskun sijoittuminen tekstiviestiin, julkaisua edeltäviin lehdessä käsiteltyihin aiheisiin sekä yhteiskunnan tapahtumiin - ympäristöön, joka on saanut ihmisen kirjoittamaan ja lähettämään mielipiteensä.

Sananlaskuja voidaan käyttää lähes missä tarkoituksessa tahansa. Niiden käyttötilanteet ovat joko keskustelua, jossa sananlaskuja käytettään vertaispuheessa, tai sitten kyse on kasvatuspuheesta eli eriarvoisten ihmisten välisestä puheesta, jossa sananlaskun kuulija on valta-asemaltaan sen esittäjää vähäisempi (Briggs 1988; kasvatuspuheesta ks. Granbom-Herranen 2008). Sanomalehteen lähetetyt tekstiviestit ovat vertaisviestintää, jossa nämä molemmat funktiot yhdistyvät. Tekstiviesteissä sananlaskuilla on sekä opastava, kasvatuspuheen kaltainen funktio että vertaispuheen kaltainen retorinen tehtävä, jonka tarkoituksena on koristella puhetta tai selventää sanottua.

\section{KÄSITYKSET HULLUUDESTA SANANLASKUJEN TAUSTALLA}

Sananlaskut edustavat yhtä muuttumattomimmista ja pysyvimmistä suullisen perinteen muodoista. Vielä 1950-luvulla arvioitiin vain kolmasosan sananlaskuista muuttuneen sadan vuoden kuluessa (Kuusi 1990). Nyt tilanne lienee toinen, mutta 2000-luvulla käytettyihin sananlaskuihin kätkeytyy oletettavasti ainakin 1800luvun ilmiöitä ja käsitteitä. Näin ollen myös se, että sananlaskuissa käytetään sanaa hullu, kertoo kyseisen ilmiön olleen olemassa. Ilman kontekstitietoja ei pelkän sananlaskun perusteella kuitenkaan ole syytä tehdä päätelmiä ilmiöstä tai sille annetuista merkityksistä.

Ensimmäiset sanakirjamerkinnät käsitteestä hullu löytyvät suomen kirjakielen syntyajoilta, samoin hölmöä tai taitamatonta ihmistä tarkoittanut tyhmä. Sana tuhma mainitaan sanakirjoissa taitamattoman tai tyhmän vastineena 1800 -luvulta alkaen (Suomen sanojen alkuperä 2001). Nykysuomen sanakirja (1983) määrittelee hullun tarkoittavan inmistä, joka toisin kuin järkevä tai täysjärkinen inminen on järjetön, älytön, mieletön, mielipuoli, mielisairas, tyhmä, hupsu tai houkka. Hullut ajatukset ja teot osoittavat toimijan tyhmyyttä, epäviisautta, harkitsemattomuutta tai lyhytnäköisyyttä. Sanakirjamääritelmän mukaan tyhmä ihminen puolestaan ei ole älykäs eikä järkevä. Hän on käsitys- tai ajatuskyvyltään heikko; toisin sanoen hän on yksinkertainen sekä heikkoälyinen tai -järkinen, huonolahjainen, kova- tai huonopäinen, typerä, hassu, hullu, hupsu, houkka tai vain hölmö. Tuhma on puheessa tarkoittanut tyhmää, typerää tai yksinkertaista inmistä. Nykyisin tuhma on kadottanut vanhan merkityksensä. Sananlaskuja, jotka sisältävät saneen hullu on runsaasti, perusteoksistakin (ks. loppuviite 1) niitä löytyy yli viisisataa. Sane tyhmä puolestaan sisältyy niissä vain noin sataan ja sane tuhma vain vajaaseen seitsemäänkymmeneen sananlaskuun. Joitakin näistä mainitaan tässäkin katsauksessa.

Käsitys hulluudesta on muodostunut ja muuttunut vuosisatojen kuluessa, mutta samoin kuin sananlaskut, arjen käytänteet muuttuvat hitaasti. Kylähulluus lienee 
tunnetuin hulluuteen liittyvä ilmiö folkloristeille. Se on varsin suomalainen ilmiö, jonka nimitys on ilmeisesti ollut puhekielessä käytössä kauemmin kuin sanakirjoissa (ks. Rantala 2009, 26-29, 33-34). ${ }^{4}$ Vaikka kylähullun on koettu uhmaavan yhteisön yhdenmukaisuuden vaatimusta toimiessaan omien mieltymyksiensä mukaan (Ylikangas 1990, 49), on yhteisön katsottu tarvinneen ja tarvitsevan hullunsa, koska toimittaessa normeja vastaan niiden tarpeellisuus yhteisölle korostuu (Knuuttila1990, 41). Ehkä tämä hyväksytty erilaisuus on vaikuttanut siihen, että käsitteestä hullu ei ole tullut vain sairautta tai mielenvikaisuutta kuvaava sana, vaan arkikielessä se on yhdistynyt lähinnä epätavallisuuteen tai outouteen. Hulluuden kriteerit vaihtelevat. Se, mikä on hulluutta joskus ja jossain, ei sitä toisessa ajassa ja paikassa olekaan. Syitä rajan määrittelyyn löytyy useita: poliittisia, oikeudellisia, taloudellisia, yhteiskunnallisia ja lääketieteellisiä. Hulluuden tulkinta on ja on ollut aikakausi- ja ryhmäsidonnainen tapahtuma. (Pietikäinen 2013, 12-15.) Kyse ei ole yksinomaan tietyn sanan käytöstä vaan käsitteen määrittelystä.

Vasta psykiatrian kehittymisen myötä 1600-luvulta alkaen alkoi Länsi-Euroopassa yhteisön normien vastainen epätavallinen käytös leimautua sairaudeksi. Suomessa hulluudesta tai mielenvikaisuudesta tuli virallisesti sairaus 1800-luvulla, ja myös sen aikaiset hulluuden määrittelyt ovat vaikuttaneet vielä 1900-luvun lainsäädäntöön. Sairaudeksi määrittelyn myötä alkoi myös potilaiden lääkehoito sairaaloissa. Siihen asti vastuu oli ollut isäntävallan käyttäjillä - vanhemmilla, isännillä ja laitosten johtajilla. (Mäkelä 2008; Pietikäinen 2013, 15, 65-69, 160-161.)

Hulluuden, kuten myös kylähulluuden, ilmeneminen ihmisessä on liitetty joko myötäsyntyisyyteen, ihmisen sairauteen tai jumalten vaikutukseen ihmisessä (Rantala 2009, 36-39; Pietikäinen 2013, 30). Platon (1999, 265a) toteaa Sokrateen puheeseen viitaten hulluutta olevan "kahta lajia, joista toinen johtuu inhimillisistä sairauksista, toinen jumalten väliintulosta, joka suistaa inmisen tutuilta uriltaan". Kenties vanhat suomalaiset sananlaskut puhuvat myös tästä jälkimmäisestä todetessaan hullujen olevan Jumalan erityissuojelussa, kuten seuraavissa traditionaalisissa sananlaskuissa: "Kyllä Jumala hullut hoitaa, katsokaat viisaat itseänsä" (K 1990); "Kyl Jumala hullut hoitaa, kattokoh vaan viisaht eteheh" (N\&H 1953) sekä "Kyllä Luoja hulluista huolen pittää, kun voan viisaat eteensä kahtoo"; "Jumala ei hulluja hukuta" ja "Pitäkööt viisaat huolen itsestään, kyllä se jumala hullut elättää" (L\&H 1997). Näissä ei siis, ainakaan välttämättä, ole kyse Sokrateen viittaamien jumalten osallisuudesta, mutta sananlaskut, vaikkakin kontekstittomat, kertonevat hulluuden olevan yhtäältä selittämätön ilmiö ja toisaalta olemassa oleva olotila. Tarkastelemissani 2000-luvun tekstiviestiaineiston sananlaskuissa Luoja tai Jumala ei kuitenkaan yhdistynyt hulluuteen ilmiönä liittyviin käsitteisiin hullu tai tyhmä.

\section{Aineisto JA MENETELMÄ}

Katsauksen aineistona on vuosina 2006-2010 Salon Seudun Sanomiin mielipidesivulle lähetetyt yli 68000 tekstiviestiä. Käyttämäni sananlaskun määrittelyn mukaisesti olen ottanut tarkasteltaviksi saneisiin hullu ja tyhmä tukeutuen myös

$4 \quad$ Vuonna 2016 päivitetty verkossa toimiva Kielitoimiston sanakirja tuntee sanan, mutta esimerkiksi Nykysuomen sanakirja vuodelta 1983 ei. 
Liisa Granbom-Herranen: Nykypäivän sananlaskujen hullu

viittaukset sananlaskuihin. Olen pyrkinyt löytämään traditionaalisille sananlaskuille perusmuodon aiemmin mainituista perusteoksista. Perusmuoto ei tässä välttämättä ole alkuperäisin tai vanhin vaan ymmärrettävissä oleva muoto. Perusmuodon esittämisen tarkoitus on selkeyttää esimerkkejä. Joidenkin uusien sananlaskujen perusmuoto löytyy Pasi Heikuran (2004) ja Matti Kuusen (1988) teoksista, ja osa on johdettu tekstiviestiaineistosta sekä aiemmissa tutkimuksissa käyttämieni 2000-luvun sanomalehtien sananlaskuaineistoista.

Salon Seudun Sanomien Tekstarit-palsta on sanomalehdessä julkaistava mielipidekirjoitusosasto, jonne kannanottoja voi lähettää ainoastaan tekstiviestin muodossa. Palstan julkaisu alkoi vuoden 2006 elokuussa jatkuen edelleen. Se ilmestyy joka päivä keskeisellä paikalla, lehden pääkirjoitussivun oikeassa alakulmassa. Päivittäin julkaistaan 15-25 tekstiviestiä, mikä on noin kymmenen prosenttia julkaistaviksi lähetetyistä viesteistä. Useimmiten Tekstarit-palstalla on luettavissa yhdestä neljään sananlaskua. Vuosina 2006-2010 lehteen lähetetyistä tekstiviesteistä vajaassa kolmessasadassa tekstiviestissä oli sane hullu ja yli viidessäsadassa tekstiviestissä sane tyhmä (kuvio 1). Toisin sanoen tekstiviesteissä sane hullu tai tyhmä esiintyy joko sananlaskussa tai sitä kehystävässä tekstiviestissä. Kuten katsauksen alussa on mainittu, sananlaskuaineistojen perusteoksissa sama sananlasku liittyy usein käsitteisiin hullu ja tyhmä. Lisäksi monissa sananlaskuissa myös käsite tyhmä esiintyy synonyymina hullulle ja tuhma on aiemmin esiintynyt sananlaskuissa tyhmän vastineena (ks. perusteokset). Näin ollen poimin tekstiviestiaineistosta saneet hullu, tyhmä sekä tuhma. Tekstiviesteissä sane tuhma ei kuitenkaan liittynyt sananlaskuihin.

\section{KUVIO 1. Ilmiöön hullu kohdistuneet sananlaskut ja tekstiviestit käsitteiden hullu ja tyhmä yhteyksissä.}

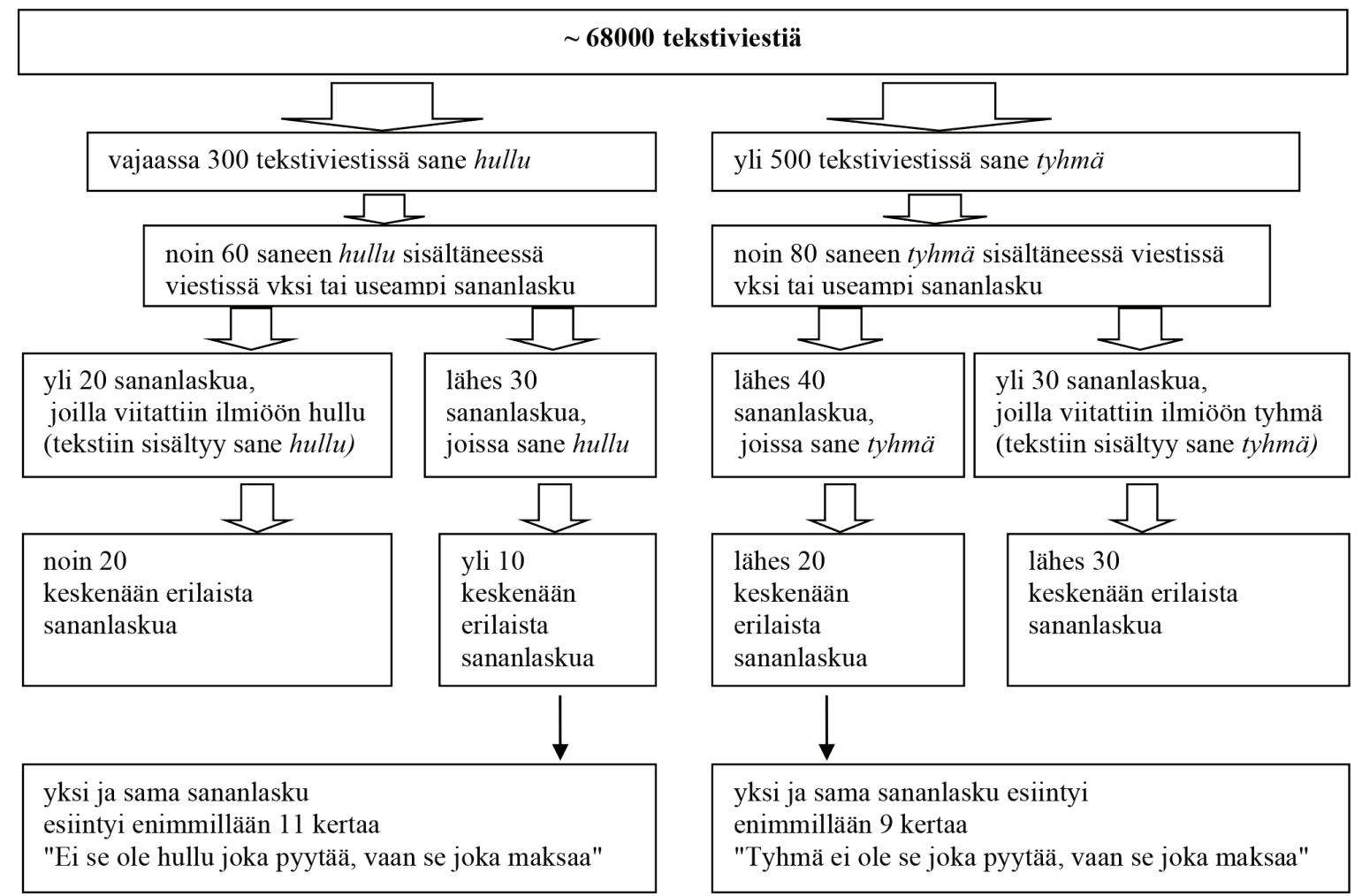


Tutkimusmenetelmän suhteen keskeisimpiä lähtökohtiani on ollut Juha Varton (1995, 95) näkemys: "[t]ieteelliselle tutkimukselle ei ole olemassa sellaista metodia tai muuta välinettä, joka olisi valmiina olemassa ennen tutkimusta". Käytetyt menetelmät voivat osoittautua toimiviksi vain ja ainoastaan mikäli ne osoittavat ottavan haltuunsa alueen, jota niillä oletetaan tutkittavan. Tutkimusmenetelmäni on sisällönanalyysi, joka mahdollistaa käsitysten tarkastelun, ja sen puitteissa voi eri vaiheissa käyttää kulloinkin tarkoituksenmukaisia menetelmiä ilmiöiden ja niiden manifestaatioiden käsittelyyn (ks. Huhtamäki \& Parviainen 2013, 246). Kuitenkaan aineiston ilmisisältö eli tässä se, mitä sananlasku sanoo, ei ole tulkittavissa varsinaisina asenteina (ks. Eskola 1975, 110), joten tulkinta on analyysin osa. Etsiessäni sananlaskuista ilmiötä hullu olen tarkastellut ilmiöihin hullu ja tyhmä käyttökonteksteissaan liittyviä käsityksiä ja niille annettuja merkityksiä. Aineiston käsittelyyn olen käyttänyt sekä laadullista että määrällistä sisällön erittelyä. Aineistonkäsittelyn tuottamia tietoja olen sisältöjen tiivistämiseksi työstänyt kategorisoinnin ja teemoittelun avulla. Tekstiviestiaineistossa mielenkiinto kohdistuu ensisijaisesti manifestoituviin sisältöihin. Manifestoituva sisältö on tekstissä annettu viesti eli sananlaskun kontekstiin kiinnitetty tulkinta (ks. Graneheim \& Lundman 2004, 106).

Aineiston käsittely on alkanut aineistokokonaisuuteen tutustumisella eli selauslukuvaiheella, jolloin tarkkailun kohteina olivat aineistossa toistuvat ilmaisut. Tämä on tarkoittanut tuhansien sivujen aineiston lukemista useaan kertaan pitkän ajan kuluessa. Tekstiviestien joukossa oli sekä sanalaskuja, joissa esiintyi sane hullu tai tyhmä sekä sananlaskuja, joilla selitettiin hullun ja tyhmän inmisen käyttäytymistä. Samalla hahmottui sananlaskujen käyttökonteksti eli tarkasteluyksikkö ja analyysiyksikön asema siinä. Tässä tutkimuksessa tarkasteluyksikkö on tekstiviesti, joka sisältää saneet hullu tai tyhmä, tai molemmat, joko sananlaskussa tai sananlaskua kehystävässä tekstissä. Ensimmäisten vuosien tekstiviestit rajoittuivat käytössä olleisiin 160 merkkiin, mutta viesti on voinut muodostua useammasta kuin yhdestä tekstiviestistä. Tässä analyysiyksikkönä on sananlasku. Analyysiyksikön ja sen tarkasteluyksikön tunnistamista seurasi niiden irrottaminen aineistosta jatkokäsittelyä varten. Tiedon tiivistämisessä ensimmäinen vaihe oli yksiköiden yhdistäminen kategorioiksi. Kategoria muodostuu ryhmästä sisältöjä, joilla on jokin yhdistävä tulkittu tekijä. Sananlaskujen tekstiviesteistä luettavista tulkinnoista oli löydettävissä samankaltaisuuksia, joiden perusteella muodostui sananlaskun tarkoitteeseen perustuen 17 kategoriaa. Tavoitteenani on ollut ilmiötä kuvaava tieto. Kategorioiden tuottama tieto tiivistyy neljään hulluutta ja tyhmyyttä (ilmiöitä hullu ja tyhmä) kuvaavaan teemaan: 1) raha, 2) seuraukset, 3) käyttäytymisen piirteet ja 4) yhteisön jäsenenä eläminen. Teemoittelun tulokset ovat olleet systemaattisen analyysin perusta.

Käsityksiä kuvattaessa tutkija on aina tulkitsija, joten sisällönanalyysissä menetelmän sovelluksen kuvaus tarjoaa pohjan tutkimuksen evaluointiin. Luotettavan tutkimuksen ehtoja ovat riittävä aineisto, soveltuvat menetelmät sekä mahdollisuus tutkimuksen toistettavuuteen. Katson näiden toteutuvan tässä, mutta tutkimuksen yleistettävyyttä ne eivät takaa. Sisällönanalyysin validiutta määrittävät juuri toiminnan kuvaus ja siihen liitettyjen selitysten ja tulkintojen yhteensopivuus. Eettisyyttä puolestaan on se tapa, jolla tutkija suhtautuu tutkimustietoon. Kaiken 
Liisa Granbom-Herranen: Nykypäivän sananlaskujen hullu

[http://www.elore.fi/arkisto/1_16/granbom-herranen.pdf]

kaikkiaan "kelvollisena" voidaan Varton $(1992,14)$ mukaan pitää tutkimusta, kun sekä tutkimuskäytänteet että tutkimustulokset ovat eettisesti hyväksyttäviä. Kontekstisidonnaisten käsitysten analyysimenetelmänä sisällönanalyysi tarjoaa varsin systemaattisen viitekehyksen sekä aineiston tiivistämiseksi että analyysin toteuttamiseksi (ks. Stemler 2001).

\section{TEKSTIVIESTIEN SANANLASKUJEN KERTOMAA}

Kuten edellisessä luvussa olen todennut, hulluuden ja tyhmyyden yhteys sananlaskuihin perustuu suomalaisiin traditionaalisiin sananlaskuihin (ks. perusteokset, loppuviite 1). Tekstiviestiaineistossa nämä ilmiöt kuvautuvat käsitteillä, joiden hakemisessa tukeuduin saneisiin. Kuten kuviosta 1 ilmenee, lähes kolmestasadasta saneen hullu sisältäneestä tekstiviestistä löytyi noin kuusikymmentä yhden tai useamman sananlaskun sisältänyttä viestiä. Perusmuodoltaan erilaisia sananlaskuja oli yli kolmekymmentä. Vastaavasti yli viidestäsadasta saneen tyhmä sisältäneestä tekstiviestistä löytyi noin kahdeksankymmentä yhden tai useamman sananlaskun sisältänyttä viestiä ja lähes viisikymmentä erilaista sananlaskua. Vertailutietojen puuttuessa ei lukumääristä voi tehdä johtopäätöksiä suhteessa sananlaskujen yleiseen esiintymiseen, tietyn sananlaskun esiintymiseen tai tiettyä ilmiötä käsittelevien sananlaskujen olemassaoloon. Kategorisointi ja teemoittelu sekä niiden perusteella tehtävät tulkinnat ovat keskeinen osa sisällönanalyysiä, mutta ne ovat kaikesta huolimatta aina tutkijan tulkintoja (Eskola ja Suoranta 2008). Olen pyrkinyt ymmärtävään tulkintaan. Seuraavaksi kuvaan aineistosta muodostuneet teemat ja niiden sisällön.

Raha. Suurin osa, noin kolmannes, käytetyistä sananlaskuista liitti hulluuden sekä tyhmyyden rahankäyttöön tai yleensä taloudelliseen toimintaan ja nimenomaan kyvyttömyyteen siinä. Näin ollen hullu ihminen maksaa ylihintaa ja tyhmä ihminen ei ymmärrä tulevansa taloudellisesti hyväksikäytetyksi. Mielenkiintoista on, että eniten käytettyjen hullu ja tyhmä -sananlaskujen, tai niihin viittausten, perusmuoto on oikeastaan sama: "Ei se ole hullu joka pyytää, vaan se joka maksaa" ja "Tyhmä ei ole se joka pyytää, vaan se joka maksaa". Molempia käytettiin yhtä paljon; joka seitsemäs sananlasku liittyi näihin. Kyseessä on uusi sananlasku, joka ei sisälly sananlaskuaineistojen perusteoksiin. Tosin Henrik Floriniuksen tallentamana tunnetaan perusmuodossaan samankaltainen sananlasku "Ei se ole hullu joka anoo vaan joka antaa" (K 1990), alkuperäisessä muodossaan "Ei se hullu ole / joca ano; wan joca anda" (Florinius 1987). Kuitenkin juuri maksajaksi joutuminen on tekstiviestin sananlaskuissa keskeisesti esillä, joten Floriniuksen muistiin merkitsemää kontekstitonta sananlaskua ei ole syytä pitää sen perusmuotona. Kummankin tekstiviesteissä esiintyvän sananlaskun yhteydessä vastakohtana on järkevä tai jopa ovelaksi tulkittavissa oleva toiminta, kuten seuraavissa esimerkeissä: "Ryöstöä. Vanha totuus: Ei se ole hullu, joka pyytää. Se on, joka maksaa... -Jäätelökauppias tietää sen" (SSS, lähetetty 4.5.2007)5 ja "Muistutus. Jos asunnon hinta 200t euroa, se on vanhassa rahassa 1,2 miljoonaa. Tyhmä ei ole se joka pyytää, vaan

$5 \quad$ SSS $=$ Salon Seudun Sanomien tekstiviestipalstalle julkaistavaksi lähetetty tekstiviesti, viestin lähetyspäivämäärä. Tekstiviestit ovat alkuperäisessä, lehden toimitukselle saapuneessa muodossa. Tekstiviestien lähettäjät esiintyvät valitsemallaan nimimerkillä. Puhelinnumero, josta viesti on lähetetty, on vain toimituksen tiedossa. 
se joka maksaa. Asuntojen hinnossa edelleen 50\% ilmaa. Tietäjä" (SSS, lähetetty 27.1.2008). Ensimmäisessä viestissä käytetään sananlaskun merkitsijänä (engl. introducer tai marker, ks. Čermák 2004) huomautusta "vanha totuus". Tällaisen sananlaskun merkitsijän tehtävänä on yhtäältä kiinnittää lukijan (kuulijan) huomio seuraavaksi tulevaan sananlaskuun ja toisaalta lisätä viestin painoarvoa.

Rahaan liittyy myös sen ansaitseminen. Noin puolet hulluuteen tai hullun käyttäytymiseen liittyvistä sananlaskuista käsitteli rahaa, tyhmyyteen liittyvistä sananlaskuista vastaavasti joka viides. Seuraavassa viestissä sananlasku puhuu pienipalkkaisuudesta ja tunnistuu alkuosansa kautta. Ilmaisu "pätkäksi ryhtyminen" viittaa osa-aikaiseen työhön: "Kokemusta on. Olen täysin samaa mieltä! Olen harkinnut ryhtymistä 'pätkäksi', hullu paljon työtä tekee" (SSS, lähetetty 17.4.2009). Osalla käytetyistä sananlaskuista on varsin vakiintunut asema kielessä, ja tämä on yksi niistä. Sananlasku, jonka perusmuoto "Hullu paljon työtä tekee, viisas pääsee vähemmällä", tunnetaan jo 1600-luvulta ja se on mukana kaikissa perusjulkaisuissa. ${ }^{6}$

Seuraukset. Tekstiviestien sananlaskut esittävät varsin yksimielisesti sekä hulluuteen että tyhmyyteen kuuluvan ymmärtämättömyyden. Tämä tarkoittaa ymmärtämättömyyttä niin tekojen ja tapahtumien vaikutuksista kuin itse tehtyjen valintojen seurauksista. Myös toimimattomien ratkaisujen esittäminen kertoo vaikeudesta ymmärtää syiden ja seurausten suhdetta. Tämä teema kattoi viidenneksen sekä ilmiöön hulluus että tyhmyys liitetyistä sananlaskujen tarkoitteista.

Seuraavassa sananlasku selvittää hullun käyttäytymisen johtavan ei-toivottuihin seurauksiin: "Naiset hulluna äänesti pahvi saulia, samalla kokoomusta joka ei ole koskaan ollut pienipalkaisten puolella. - sitä saa mitä tilaa" (SSS, lähetetty 12.9.2007). Perusmuodossaan "Sitä saa mitä tilaa" esiintyvä sananlasku ei sisällä sanetta hullu tai tyhmä. Tämä uusi sananlasku mainitaan Heikuran $(2004,84)$ teoksessa "vastavuoroisuusnasautuksena", "ravintolatoteamuksena" ja "letkautuksena" käyttöohjeiden kera. Tekstiviestin lähettäjä esittää äänestäjien, erityisesti naisten, toimivan kuin hullut valitessaan ehdokkaansa ulkonäön perusteella miettimättä seurauksia. Tällainen käytös ei ole hyväksyttävää eikä järkevää. Seuraavassa esimerkissä tekstiviestissä kuvataan hullun toimintaa epäillen toiminnan seuraamuksia sananlaskuun tukeutuen. Myöskään tämä sananlasku ei sisällä sanetta hullu tai tyhmä: "Suomen kansa on tullut hulluksi kaikesta rikkaudesta ja hyvinvoinnista, joka on osunut kohdallemme. Miten hullu kansa selviää tästä muutoksesta - Ken elää, hän näkee" (SSS, lähetetty 9.6.2008). Sananlasku on perusmuodossaan "Ken elää, se näkee" (L\&H 1997). Tekstiviestin sanoma on, että vasta ajan kuluessa voi päätellä, kuinka hullu - tässä tapauksessa koko kansa - selviää tilanteesta. Lopputulos on arvaamaton.

6 "Hullu paljon työtä tekee, elää viisas vähemmälläkin", "Hullu paljon työtä tekee" sekä "Tuhma paljon työtä tekee, elää viisas vähemmälläkin" (K 1990); "Hullu paljon työtä tekee, viisas elää vähemmälläkin" (N\&H 1953) sekä sananlaskut "Hullu paljon tekee, vähemmälläkin aikoin tulee", "Hullu paljo työtä tekkyö, elliehä se viisas vähemmälläki" ja "Tuhmahan se työtä teköö, viisas elää virallaan" (L\&H 1997). Lisäksi kyseinen sananlasku löytyy uudemmasta Heikuran (2004) sananlaskuja (ja muita latteuksia) sisältävästä kirjasta muodossa "Hullu paljon töitä tekee, viisas pääsee vähemmällä". Mutta kuten edellä mainitsin, teokset esittävät sananlaskut luetteloituina ja osittain koottuina toimittajan tulkinnan mukaisesti sekä tukeutuen sananlaskun oletettuun perusmerkitykseen (engl. standard proverbial interpretation, ks. Norrick 1985). 
Hulluuden ja tyhmyyden seuraukset voivat olla myös aivan konkreettisia. Seuraavassa esimerkissä sakottaminen tarkoittaa konkreettista rahan menetystä. Tekstiviestin aloittava sananlasku "Rahalla on valtaa" tukee tyhmyyteen liittyvän sananlaskun sanomaa - kuten myös sen lopussa käytetty sananlaskun merkitsijä: "sanoo vanha sananlasku". "Rahalla on valtaa, mutta miksi ostaa rakennuksia joita ei voi korjata. Tyhmyydestä sakotetaan, sanoo vanha sananlasku. Nimim. Tarkka euroistaan." (SSS, lähetetty 17.11.2007).

Käyttäytymisen piirteet. Tähän teemaan sisältyy useita tekstiviesteissä vain kerran esiintyviä sananlaskuja. Toisin kuin kahdessa ensimmäisessä teemassa myöskään piirteet, joihin niillä viitataan, eivät muodosta yhtenäistä kokonaisuutta hulluudesta tai tyhmyydestä. Tähän teemaan sisältyy noin neljännes kumpaankin ilmiöön liitetyistä sananlaskuista. Yksi piirteistä on, että tyhmä tai hullu tekee tyhmyyksiä. "Hölmöä - vielä hölmömpää on ajella maastureilla kaupungeissa. Joukossa tyhmyys tiivistyy" (SSS, lähetetty 24.12.2009). Tekstiviesti on jatkoa aiemmin lähetetylle ja ilmeisesti julkaistulle viestille, jossa kysyttiin: "Mitä järkeä on ajella pakulla, jos ei ole mitään kuljetettavaa? Nim. Hölmöä" (SSS, lähetetty 16.12.2009). Kysymys nimimerkillä "Hölmöä" kirvoitti useita vastauksia, joista kuitenkin ainoastaan yllämainitussa tukeuduttiin sananlaskuun.

Tekstiviestissä hulluus ja tyhmyys saavat usein rinnalleen älyn tai järjen, lähinnä niiden puutteen vuoksi. Seuraavaan tekstiviestiin, joka kommentoi Terveys- ja sosiaalialan ammattijärjestö Tehyn työtaistelua syksyllä 2007, sisältyy monia tällaiseen typerään käyttäytymiseen liittyviä elementtejä: "Tehy. Todistatte juuri että sanonta 'Joukossa tyhmyys tiivistyy' pätee teihin, jätätte jopa lapset hoitamatta. - Äly hoi, älä jätä" (SSS, lähetetty 18.10.2007). Ensimmäistä, uutta sananlaskua on tekstiviestissä käytetty perusmuodossaan "Joukossa tyhmyys tiivistyy" (Kuusi 1988). Tekstiviestin lähettäjä viestittää ammattiliiton jäsenten yhdessä ajattelevan ja toimivan tyhmemmin kuin yksittäiset hoitajat tekevät. Sananlaskun vakuuttelevuutta lisää huomautus "todistatte juuri että..." ennen sananlaskun merkitsijänä toimivaa ilmaisua "sanonta". Toinen, traditionaalinen sananlasku "Äly hoi, järki älä jätä" korostaa järjen puutetta. Perusteoksissa se on muodoissa "Ymmärrys hoi, äly elä jätä" (L\&H 1997) sekä "Äly hoi älä jätä, ymmärrys älä petä" (L\&H 1997).

Yhteisön jäsenenä eläminen. Sananlaskujen ja niiden käyttökontekstin kautta tyhmyyteen, mutta ei hulluuteen, liittyy vaikeus elää yhdessä muiden ihmisten kanssa. Teema sisältää neljäsosan sananlaskuista, joista liki kaikki eli 90 prosenttia liittyy tyhmyyteen tai tyhmän käyttäytymiseen. Tämä teema erottaa tarkastellut ilmiöt toisistaan. Sananlaskuja käyttävien viestien mukaan tyhmällä ei ole kykyä tulla toimeen ihmisten kanssa. Tyhmyys on tyhmän ihmisen käyttäytymistä tai tyhmän ominaisuus. Tyhmä ei ymmärrä yhteistä hyvää eikä omaa parastaan. Hän ei suvaitse erilaisuutta, ja häntä myös kohdellaan sen mukaisesti tyhmänä. "Tyhmyyttäkö. Se on tyhmyyttä jos pitää valittaa ettei tule toimeen työpaikalla eikä sukulaisten kanssa. Peilistä löytyy syyllinen. 'tosi on'"' (SSS, lähetetty 28.5.2009). Viesti on vastaus nimimerkillä "Tyhmyyttä" 26.5.2009 lähettyyn viestiin, joka kertoi työpaikan tilanteesta. 
Vuosien 2008 ja 2009 vaihteessa maataloustukineuvottelut kirvoittivat tekstiviestejä: "141 neuvottelut kesken. Mallioppilas saa taas kerran turpiinsa nim. Vain tyhmä kääntää toisenkin posken" (SSS, lähetetty 10.11.2007). Sananlasku "Jos joku lyö sinua oikealle poskelle, käännä hänelle vasenkin" on sananlaskuna toimiva raamatunlause Matteuksen evankeliumista (Matt. 5:39). Raamattuun tukeutuminen edellyttää kuulijan tai lukijan tunnistavan sananlaskun taustalla olevan auktoriteetin. Raamatunlauseiden tuntemus ja niiden käyttäminen sananlaskuina onkin, jos ei suomalainen erikoisuus, niin ainakin ominaista suomalaisessa sananlaskuja käyttävässä viestinnässä (ks. Granbom-Herranen ym. 2015).

\section{YHTEENVETO}

Sananlaskut tekstiviesteineen ja tekstiviestit sananlaskuineen välittävät käyttöyhteytensä kautta kuvaa nykypäivän hulluudesta typeränä ajattelemattomuutena. Helposti hyväksikäytetty ihminen on joko hullu ja tyhmä, joka ei ymmärrä taloudenpidosta paljoakaan. Suurin käyttäytymisen omituisuus näkyykin juuri rahankäytössä. Sananlaskuissa hulluus ei näyttäydy samanlaisena anonyymina ja kollektiivisena ilmiönä kuin tyhmyys. Kenties synonyymiksi tämän päivän sananlaskun hullulle kävisi käsite typerä merkityksessä tyhmä, yksinkertainen, älytön tai hölmö. Tekstiviesteissä sananlaskujen avulla kuvattu typeryys ei ole säälittävää, vaan enemmänkin viestien sananlaskujen kautta korostuu, jos ei vahingonilo, niin ainakin ylimielisyys - ottakoon typerys opikseen.

Hulluus ja tyhmyys, kuten kylähulluus (Rantala 2009), määrittyvät suhteessa ympäristöön. Sananlaskujen artefaktius liittää ne kiinteästi elinkaarensa aikakausien luomiin konteksteihin. Ilmauksina sananlaskut ovat hitaasti muuttuvia, mutta puheessa ja puheen kaltaisessa kirjoituksessa ne sopeutuvat jatkuvasti uusiin tilanteisiin. Vaikka ilmaisun muoto pysyy muuttumattomana, tulkinnat vaihtelevat. Koska varhaisemmista käyttökonteksteista ei useinkaan ole tietoa, ei edes muotonsa säilyttäneistä sananlaskuista tule suoraan tehdä johtopäätöksiä tapahtumista tai vallinneista asenteista. Niiden tulkinta on sidoksissa tiettyyn aikakauteen ja siinä vallinneeseen elämismaailmaan käsityksineen. Tekstiviesteissä kyse on lähinnä Charles Briggsin (1988) määrittelemästä vertaispuheesta, vertaisten välisestä viestinnästä, joka mahdollistaa oletuksen sananlaskujen tunnettavuudesta. Oletus on, että viestin kirjoittaja ja lukija jakavat jollakin lailla yhteisen kokemusmaailman, jolloin sananlaskuja voidaan lyhentää tai jättää vain viittauksen varaan viestin ymmärrettävyyden vähenemättä. Tämä ei kuitenkaan takaa viestin kirjoittajan ja lukijan tekemien tulkintojen yhtäläisyyttä.

Sananlaskujen tulkinnan olen kiinnittänyt kontekstitietojen avulla niiden tilannekohtaiseen merkitykseen. Lopputulos olisi ollut toisenlainen, mikäli tulkinta olisi perustunut paremiologiassakin yleisimmin käytettyyn menetelmään eli sananlaskujen oletettuun perusmerkitykseen (ks. Norrick 1985). Perusmerkityksen taustalla on oletus siitä, että sananlaskuilla on jokin kaiken kattava tulkinta, jonka kaikki inmiset tuntevat samalla tavalla. Tilanne on pulmallinen, sillä yhtäältä sananlaskun tilannekohtaista merkitystä ei ole mielekästä pyrkiä tulkitsemaan ilman kontekstitietoja ja toisaalta oletetun merkityksen kautta tulkinta on usein perusteeton. 
Katsauksen aineiston muodostavat julkaistaviksi lähetetyt tekstiviestit. Jotta hulluus, sitä kuvaavat sananlaskut ja niiden käyttöyhteys tähän tutkimukseen löytyivät, tarvittiin aineistoa usean vuoden ajalta yhteensä noin kolmetuhatta sivua. Lopputuloksen oli noin 120 sananlaskua, jotka kontekstinsa avulla tai sen kautta kertovat jotakin tämän päivän näkemyksistä. Aineistossa saneet hullu tai tyhmä sisältyvät joko sananlaskuun tai ne liittyvät sananlaskuun tai sananlaskuihin tekstiviestin tarjoaman kehyksen välityksellä. Olen käyttänyt näitä saneita määrittämään ilmiöitä kuvaavia käsitteitä etsiessäni kahden ilmiön, hulluuden ja tyhmyyden, mahdollista yhdistymistä käsitteessä hullu. Hulluus ja tyhmyys esiintyivät tekstiviestien sananlaskujen kuvaamina varsin samankaltaisina mutta eivät täysin samaa tarkoittavina ilmiöinä. Paikkansa piti oletus, ettei niitä yhdistetty sairauteen. Kuitenkaan käsitteet hullu ja tyhmä eivät välttämättä riitä kattamaan hulluutta ilmiönä. Aineistoa tarkastellessa mahdolliseksi lisälähtökohdaksi osoittautui esimerkiksi sane järki. Aineisto sisältää lähes 1400 tekstiviestiä, joissa se esiintyy. Tähän joukkoon kuuluu sananlaskuja, kuten "Järjen käyttö sallittu". Mielenkiintoisia ovat ennen kaikkea ne tekstiviestit sananlaskuineen, joiden sananlaskuun eivät saneet hullu tai tyhmä sisälly - kuten esimerkiksi aiemmin mainittu "Ken elää, se näkee". Niissä hyödynnetään sananlaskun kaikkeen sopeutuvaa ominaisuutta samalla, kun sananlaskulla vahvistetaan välitetyn viestin tärkeyttä.

Alkuperältään suomenkieliset sananlaskut eli suurin osa traditionaalisista sananlaskuista perustuvat puhuttuun tietoon. Modernit sananlaskut ovat usein käännöksiä, jotka alkuperäiskielessään saattavat määrittyä toisin kuin suomenkielessä. Menneisyyden käsityksiä hulluudesta ei sananlaskujen kautta löydy, sillä arkistomateriaali sisältää harvoin sananlaskuja taustoittavia tietoja. Tällöin ainoaksi varmaksi johtopäätökseksi jää tieto, että tiettynä aikana on elänyt inmisiä, jotka muistivat ja kirjasivat mainitut sananlaskut. Se, mitä informantit ovat niillä tarkoittaneet tai ovat olettaneet toisten tarkoittaneen heille kohdistetussa puheessa, jää useimmiten epävarmaksi. Tämä ei vähennä tallenteiden merkittävyyttä, mutta asettaa haasteita myöhemmille tulkinnoille. Sananlaskun kontekstiton tulkinta kertoo usein enemmän tulkitsijasta kuin esimerkiksi sananlaskun ilmentämistä arvoista.

Hulluuden, kuten muidenkin ilmiöiden, tarkastelu sananlaskujen kautta edellyttää tietoa ilmiöstä tietyssä ajassa ja paikassa; mitä ilmiöllä on tarkoitettu, miten se on näyttäytynyt ja onko sillä ollut vaikutusta yhteisössä. Lisähaaste tulee sananlaskujen käyttämästä, usein vanhasta sanastosta: sanat säilyvät, mutta merkitykset muuttuvat. Oletan, ettei varsinainen hulluustutkimus voi juurikaan hyödyntää sananlaskuja sinänsä, mutta koska sananlaskujen kieli ja käsitteet ovat aikakausija paikkasidonnaisia, voivat sananlaskut kertoa ilmiön olleen olemassa. Sananlaskujen käyttökontekstin kautta voi avautua jotakin ympäristön suhtautumistavasta.

\section{EPILOGI}

Tämän kirjoittaminen toi mieleeni isoisäni, joten olkoon tämä hänelle, suvun toistaiseksi ainoalle, jolla on ollut terveen paperit. Ne hän oli saanut 1900-luvun puolivälissä Lapinlahden sairaalasta, kolmen kuukauden hoitojakson lopuksi. "Hulluna on hyvä elää, kun ei järkeä puutu". 
Liisa Granbom-Herranen: Nykypäivän sananlaskujen hullu

[http://www.elore.fi/arkisto/1_16/granbom-herranen.pdf]

LÄHTEET

\section{Tutkimusaineistot}

Salon Seudun Sanomat, sanomalehden oma arkisto

\section{Kirjallisuus}

Briggs, Charles L. 1988: Competence in Performance. Philadelphia: University of Pennsylvania Press.

Čermák, František 2004: Text Introducers of Proverbs and Other Idioms. - Földes, Csaba \& Wirrer, Jan (toim.), Phraseologismen als Gegenstand sprach- und kulturwissenschaftlicher Forschung. Baltmannsweiler: Schneider Vehrlag Hohengehren. 27-46.

Dundes, Alan 1981: On the Structure of the Proverb. - Mieder, Wolfgang \& Dundes, Alan (toim.), The Wisdom of many. Essays on the Proverb. New York \& London: Garland Publishing. 43-64.

Eskola, Antti 1975: Sosiologian tutkimusmenetelmät 2. Porvoo: WSOY.

Eskola, Jari \& Suoranta, Juha 2008: Johdatus laadulliseen tutkimukseen. Tampere: Vastapaino.

Florinius, Henrik 1987: Sananlaskut. [Wanhain Suomalaisten Tawaliset ja Suloiset Sananlascut]. Helsinki: SKS. [1702]

Goodman, Nelson 1985: Languages of Art. An approach to a theory of symbols. Indianapolis: Hackett Publishing Company, Inc.

Granbom-Herranen, Liisa 2008: Sananlaskut kasvatuspuheessa - perinnettä, kasvatusta, indoktrinaatiota? Jyväskylän yliopisto [online]. < http://urn.fi/ URN:ISBN:978-951-39-3111-7 > [16.12.2015.]

Granbom-Herranen, Liisa 2013: "Newspapers are the schoolmasters of the common people" - Some paremiological notes of proverbs in a Finnish newspaper. Soares, Rui \& Lauhakangas, Outi (toim.), 6th Interdisciplinary Colloquium on Proverbs. Tavira: IAP. 315-328.

Granbom-Herranen, Liisa 2014: "SMS-messages - context for traditional and modern proverbs". - Jesenšek, Vida \& Dobrovol'skij, Dmitrij (toim.), Phraseologie und Kultur / Phrareology and Culture. Maribor: Mednarodna založba Oddelka za slovanske jezike in književnosti, Filozofska fakulteta. 367-381.

Granbom-Herranen, Liisa 2015: Some paremiological notes of proverbs in three Finnish newspapers. - Soares, Rui \& Lauhakangas, Outi (toim.), 8th Interdisciplinary Colloquium on Proverbs. Tavira: IAP. 404-415.

Granbom-Herranen, Liisa 2016 [tulossa]: The genre of proverb - a relic or very much alive? - Koski, Kaarina \& Frog \& Savolainen, Ulla (toim.), Genre - Text Interpretation: Multidisciplinary Perspectives on Folklore and Beyond. Helsinki: SKS.

Granbom-Herranen, Liisa \& Babič, Saša \& Voolaid, Piret 2015: Proverbial expressions in newspapers. A comparative study in Estonia, Finland and Slovenia. - Traditiones 44(3): 5-32. [online] < http://isn.zrc-sazu.si/index. php?q=sl/node/467 > [26.1.2016.] 
Liisa Granbom-Herranen: Nykypäivän sananlaskujen hullu

[http://www.elore.fi/arkisto/1_16/granbom-herranen.pdf]

Granbom-Herranen, Liisa \& Lauhakangas, Outi 2015: Table of articles in: Soares, Rui \& Lauhakangas, Outi (eds.) Interdisciplinary colloquium on proverbs, Actas ICP07-ICP14 Proceedings. Tavira: AIP-IAP, 2008-2015. November 2015. < http://www.folklore.ee/rl/fo/koostoo/tavira/index e.html > [16.3.2016.]

Graneheim, U.H. \& Lundman, B. 2004: Qualitative content analysis in nursing research: concepts, procedures and measures to achieve trustworthiness. - Nurse Education Today 24 (2): 105-112. [online] DOI: http://dx.doi. org/10.1016/j.nedt.2003.10.001 [24.1.2016.]

Grzybek, Peter 1987: Foundations of Semiotic Proverb Study. - Proverbium: International Yearbook of Proverb Scholarship Vol. 4. 39-85.

Heikura, Pasi 2004: Samoilla linjoilla. Lisää Suomen kansan latteuksia. Helsinki: Otava.

Honko, Lauri 1989: Folkloristic Theories of Genre. - Siikala, Anna-Leena (toim.), Studies in Oral Narrative. Helsinki: SKS. 13-28.

Huhtamäki, Jukka \& Parviainen, Olli 2013: Verkostoanalyysi sosiaalisen median tutkimuksessa. - Laaksonen, Salla-Mari \& Matikainen, Janne \& Tikka, Minttu (toim.), Otteita verkosta. Verkon ja sosiaalisen median tutkimusmenetelmät. Tampere: Vastapaino. 245-273.

Kielitoimiston sanakirja [online]. < http://www.kielitoimistonsanakirja.fi > [26.3.2016.]

Knuuttila, Seppo 1990: Yhdeksääkymmentä yhdeksää lajia. - Laaksonen, Pekka \& Piela, Ulla \& Lahti, Pirkko (toim.), Hullun kirjoissa. Näkökulmia suomalaiseen kylähulluuteen. Helsinki: SKS. 39-48.

Kuusi, Matti (toim.) 1988: Rapatessa roiskuu. Nykysuomen sananparsikirja. Helsinki: SKS.

Kuusi, Matti (toim.) 1990: Vanhan kansan sananlaskuviisaus. Helsinki: WSOY. [1953]

Laukkanen, Kari \& Hakamies, Pekka (toim.) 1997: Sananlaskut. Helsinki: SKS. [1978]

Lee, Keekok 1999: The Natural and the Artefactual: The Implications of Deep Science and Deep Technology for Environmental Philosophy. Lanham: Lexington Books.

Mieder, Wolfgang 2004: Proverbs. Westport, Connecticut, London: Greenwood Press.

Mäkelä, Jari 2008: Houruinhoitoasetuksesta mielenterveyslakiin. Mielisairaanhoidon ja erityisesti

tahdosta riippumattoman hoidon lainsäädännön muutoksia vuosina 1840-1991. Historian pro gradu -tutkielma [online]. Joensuu: Joensuun yliopisto. $<$ http:// urn.fi/URN:NBN:fi:joy-20080030 > [16.3.2016.]

Niiniluoto, Ilkka 2000: Tekniikan filosofia. - Lemola, Tarmo (toim.), Näkökulmia teknologiaan. Helsinki: Gaudeamus. 16-35.

Nirvi, R. E. \& Lauri Hakulinen (toim.) 1953: Suomen kansan sananparsikirja. Porvoo: WSOY. [1948]

Norrick, Neal R. 1985: How proverbs mean: semantic studies in English proverbs. New York: de Gruyter.

Nykysuomen sanakirja 1983. Porvoo: WSOY.

Pietikäinen, Petteri 2013: Hulluuden historia. Helsinki: Gaudeamus.

Platon 1999: Teokset, osa 3. Helsinki: Otava. 
Proverbium: Yearbook of International Proverb Scholarship.

Rantala, Pälvi 2009: Erilaisia tapoja käyttää kylähullua. Kalkkimaan pappi aatteiden ja mentaliteettien tulkkina 1800-luvulta 2000-luvulle. Turku: K\&H-kustannus. Reznikov, Andrey 2009: Old Wine in New Bottles. Modern Russian Anti-Proverbs. Vermont: University of Burlington.

Stemler, Steve 2001: An overview of content analysis. - Practical Assessment, Research \& Evaluation 7(17). [online]

$<$ http://pareonline.net/getvn.asp?v=7\&n=17 > [20.1.2016.]

Suomen sanojen alkuperä. Etymologinen sanakirja 1-3, 2001. Helsinki: SKS. Varto, Juha 1992: Laadullisen tutkimuksen metodologia. Helsinki: Kirjayhtymä. Varto, Juha 1995: Fenomenologinen tieteen kritiikki. Tampereen yliopisto.

Ylikangas, Heikki 1990: Kyläoriginelli-ilmiö historian näkökulmasta. - Laaksonen, Pekka \& Piela, Ulla \& Lahti, Pirkko (toim.), Hullun kirjoissa. Näkökulmia suomalaiseen kylähulluuteen. Helsinki: SKS. 49-54.

Dosentti Liisa Granbom-Herranen tekee tutkimusta Turun yliopistossa (folkloristiikka) ja Jyväskylän yliopistossa (kasvatustieteet). Folkloristiikassa hänen tutkimuksensa keskittyy sananlaskuihin. 